\title{
Haloferax larsenii sp. nov., an extremely halophilic archaeon from a solar saltern
}

Correspondence
Min Wu
wumin@zju.edu.cn

\author{
Xue-Wei Xu, ${ }^{1,2}$ Yue-Hong Wu, ${ }^{1}$ Chun-Sheng Wang, ${ }^{3}$ Aharon Oren, ${ }^{4}$ \\ Pei-Jin Zhou ${ }^{2}$ and Min $\mathrm{Wu}^{1}$ \\ ${ }^{1}$ College of Life Sciences, Zhejiang University, Hangzhou 310058, People's Republic of China \\ ${ }^{2}$ Institute of Microbiology, Chinese Academy of Sciences, Beijing 100080, People's Republic of \\ China
${ }^{3}$ Second Institute of Oceanography, State Oceanic Administration, Hangzhou 310012, People's Republic of China
${ }^{4}$ Institute of Life Sciences and the Moshe Shilo Minerva Centre for Marine Biogeochemistry, The Hebrew University of Jerusalem, Jerusalem 91904, Israel

The genus Haloferax was originally proposed by Torreblanca et al. (1986) as a member of the family Halobacteriaceae. At present, the genus comprises seven species: Haloferax volcanii (Mullakhanbhai \& Larsen, 1975), Hfx. mediterranei (Rodriguez-Valera et al., 1983), Hfx. denitrificans (Tomlinson et al., 1986; Tindall et al., 1989), Hfx. gibbonsii (Juez et al., 1986), Hfx. alexandrinus (Asker \& Ohta, 2002), Hfx. lucentense (Gutierrez et al., 2002) and Hfx. sulfurifontis (Elshahed et al., 2004).

The current taxonomic classification of the Halobacteriaceae is mainly based on $16 \mathrm{~S}$ rRNA gene sequence comparison, polar lipid composition and phenotypic characteristics (Oren et al., 1997; Grant et al., 2001; Castillo et al., 2006). All Haloferax species described so far possess diphytanyl ether derivatives of sulfated diglycosyl diether but do not contain phosphatidylglycerol sulfate (Grant et al., 2001). In phylogenetic trees based on 16S rRNA gene sequences, they form an independent cluster, the nearest taxon being

The GenBank/EMBL/DDBJ accession number for the 16S rRNA gene sequences of strains ZJ206 ${ }^{\top}$, ZJ203 and ZJ204 are AY838278, DQ458847 and AY838279, respectively.

Phase-contrast photomicrographs and transmission electron photomicrographs of strain ZJ206 ${ }^{\top}$ are available as supplementary figures in IJSEM Online.
Halogeometricum borinquense. Additionally, most members of the genus Haloferax are extremely pleomorphic and require relatively low salt levels for growth in comparison with other members of the Halobacteriaceae.

We have isolated three strains of extremely halophilic archaea from a mixture of mud and brine obtained from a solar saltern $\left(122^{\circ} 17^{\prime} \mathrm{N} 29^{\circ} 55^{\prime} \mathrm{E}\right)$ located in the Zhoushan archipelago, Zhe-Jiang Province, China. The water sample (approx. $50 \mathrm{ml}$ ) was filtered through 0.45 and $0.22 \mu \mathrm{m}$ filters in sequence and then the $0.22 \mu \mathrm{m}$ membrane was added to DSMZ medium 823 and plated by using a 10 -fold dilution-series method. The plates were incubated aerobically at 25 and $37^{\circ} \mathrm{C}$. After 1-2 weeks incubation, representative colonies were picked and maintained on SG medium (Sehgal \& Gibbons, 1960) at $37^{\circ} \mathrm{C}$. Strains were purified by repeated restreaking; purity was confirmed from the uniformity of the cell morphology. Cell morphology and motility were examined by using phase-contrast microscopy (BX40; Olympus/Axiovert 135TV; Zeiss) and transmission electron microscopy (H-600; Hitachi). The cells of all three isolates were very pleomorphic; in cultures grown at the highest salinities, elongated cells were common (see Supplementary Fig. S1 available in IJSEM Online). The cells showed motility, but we did not observe flagella by electron microscopy (Supplementary Fig. S2). The cultures 
were pink in colour as a result of the presence of bacterioruberin carotenoids. Phenotypic characteristics were tested according to $\mathrm{Xu}$ et al. (2005), as mentioned previously in the minimal standards for the description of new taxa in the order Halobacteriales (Oren et al., 1997). Parallel tests were performed with the strains $H f x$. sulfurifontis JCM $12327^{\mathrm{T}}$ and $H$ fx. volcanii CGMCC $1.2350^{\mathrm{T}}$.

Total lipids were extracted by using the modified method of Kamekura \& Kates (1988). Polar lipids were separated by two-dimensional silica-gel TLC. Phospholipids were detected with Zinzadze reagent. Glycolipids were analysed by spraying the plate with $0.5 \% 1$-naphthol in methanol/ water $(1: 1)$ and then with sulfuric acid/ethanol $(1: 1)$ before heating it at $120^{\circ} \mathrm{C}$ for $10 \mathrm{~min}$ (Xin et al., 2000). The glycolipid analysis indicated the presence of sulfated diglycosyl diether and the absence of phosphatidylglycerol sulfate.

The $16 \mathrm{~S}$ rRNA genes were analysed as described previously (Xu et al., 2005). Phylogenetic trees were constructed by using the neighbour-joining method with the MEGA3 program package (Kumar et al., 2004), after multiple alignment of the data by CLUSTAL_X (Thompson et al., 1997). The 16S rRNA gene sequences of the three isolates showed $99.8-100 \%$ similarity with respect to each other. Sequence similarity analysis by the FASTA network service revealed that the strains shared 96.4-97.4\% similarity with the type strains of previously described Haloferax species, and $92.3-92.5 \%$ similarity with $\mathrm{Hgm}$. borinquense PR $3^{\mathrm{T}}$, its closest relative outside the genus Haloferax. Both the neighbour-joining tree (Fig. 1) and the maximum-parsimony tree (not shown) indicated that the isolates are separate from Haloferax species and cluster most closely with $H f x$. sulfurifontis $\mathrm{M}^{\mathrm{T}}$.

The DNA G + C content of strain ZJ206 ${ }^{\mathrm{T}}$ as determined by thermal denaturation $\left(T_{\mathrm{m}}\right)$ (Marmur \& Doty, 1962) was found to be $62.2 \mathrm{~mol} \%$, which is within the range reported for Haloferax species (Grant et al., 2001). DNA-DNA

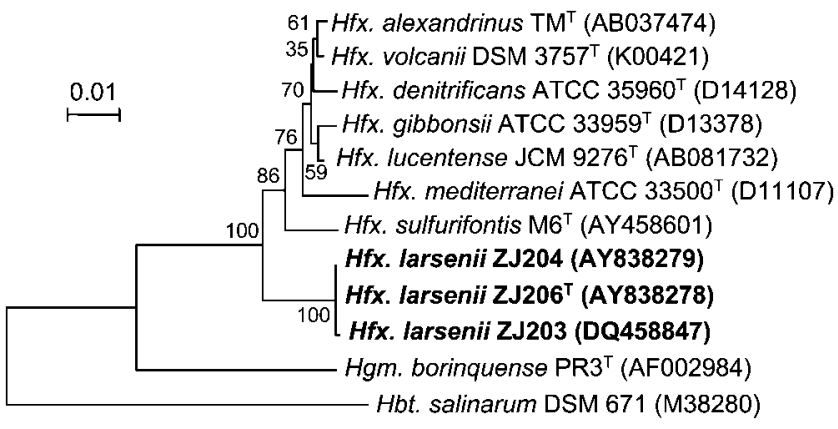

Fig. 1. Neighbour-joining phylogenetic tree, based on $16 \mathrm{~S}$ rRNA gene sequences, showing the relationships of strain ${\mathrm{ZJ} 206^{\top}}^{\top}$ and related taxa. Numbers at branching nodes are bootstrap values (percentages of 1000 resamplings). Bar, 0.01 substitutions per nucleotide position. hybridizations were performed by using the thermal denaturation and renaturation method of De Ley et al. (1970), as modified by Huß et al. (1983), with a Beckman DU 800 spectrophotometer. DNA-DNA relatedness levels for strain ZJ206 ${ }^{\mathrm{T}}$ with respect to $H f x$. sulfurifontis JCM $12327^{\mathrm{T}}$ and $H f x$. volcanii CGMCC $1.2350^{\mathrm{T}}$ were 48 and $44 \%$, respectively. Comparisons of phenotypic properties (Table 1) also indicated differences (such as motility, hydrolysis of substrates and acid production from sugars) between strain $\mathrm{ZJ} 206^{\mathrm{T}}$ and Haloferax species.

The phenotypic, phylogenetic and chemotaxonomic data suggest that strain ZJ206 ${ }^{\mathrm{T}}$ is a member of the genus Haloferax. Differences in phenotypic characteristics (Table 1) and 16S rRNA gene sequences, together with the DNA-DNA hybridization data, justify the creation of a novel species. We propose to name the novel species in honour of Professor Helge Larsen, who has contributed much to our understanding of halophilic micro-organisms, and who originally described the type species of the genus Haloferax. Thus, strain ZJ206 ${ }^{\mathrm{T}}$ represents a novel species within the genus Haloferax, for which the name Haloferax larsenii sp. nov. is proposed.

\section{Description of Haloferax larsenii sp. nov.}

Haloferax larsenii (lar.se' ni.i. N.L. gen. n. larsenii of Larsen, named in honour of Professor Helge Larsen, one of the pioneers of halophile research).

Gram-negative. Extremely pleomorphic, motile, occurring mainly as irregularly shaped cells $(0.8-1.5 \mu \mathrm{m}$ in diameter). Cells grown at the highest salinities are often elongated. Colonies on complex agar medium are 1-2 $\mathrm{mm}$ in diameter, smooth, circular, elevated and orange-red. Halophilic. Cells lyse immediately in distilled water after $2 \mathrm{~h}$ with $10-20 \mathrm{~g}$ $\mathrm{NaCl} \mathrm{l}^{-1}$. The $\mathrm{NaCl}$ concentration for growth is between 1 and $4.8 \mathrm{M}$, with an optimum at 2.2-3.4 M. Saturated $\mathrm{NaCl}$ inhibits growth in liquid medium. Growth occurs in media containing more than $5 \mathrm{mM} \mathrm{Mg}^{2+}$, the optimum $\mathrm{Mg}^{2+}$ concentration being between 20 and $500 \mathrm{mM}$. The $\mathrm{pH}$ range for growth is 6.0-8.5, with an optimum at $\mathrm{pH} 6.5-7.0$; the temperature range for growth is $25-55^{\circ} \mathrm{C}$, with an optimum at $42-45^{\circ} \mathrm{C}$. Chemoorganotrophic. Oxidase- and catalasepositive. Anaerobic growth with arginine or DMSO does not occur. Positive for indole formation. Nitrate is reduced to nitrite. Grows anaerobically on nitrate, with the production of gas. $\mathrm{H}_{2} \mathrm{~S}$ is produced from thiosulfate. Starch and Tweens 40 and 80 are hydrolysed. Gelatin is hydrolysed; casein is not hydrolysed. The following substrates are utilized for growth: glucose, glycerol, mannose, starch, maltose, sucrose, glutamate, alanine, ornithine, fumarate, malate, pyruvate, succinate and lactate. Arabinose, lactose, mannitol, rhamnose, sorbitol, galactose, ribose, xylose, arginine, lysine, aspartate, glycine, acetate, propionate and citrate are not utilized for growth. Acid is produced from glycerol and maltose and, to a lesser extent, on glucose, fructose and sucrose. Sensitive to novobiocin, bacitracin, anisomycin, aphidicolin and rifampicin, but not to 


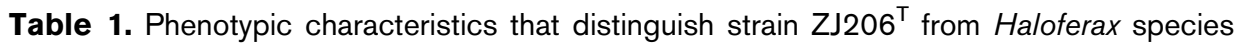

Taxa: 1, strain ZJ206 ${ }^{\mathrm{T}}$; 2, Hfx. volcanii; 3, Hfx. denitrificans; 4, Hfx. gibbonsii; 5, Hfx. mediterranei; 6, Hfx. alexandrinus; 7, Hfx. lucentense; 8, Hfx. sulfurifontis. The data are based on our comparative studies with Hfx. volcanii and Hfx. sulfurifontis, as well as on data derived from Asker \& Ohta (2002), Elshahed et al. (2004), Grant et al. (2001), Gutierrez et al. (2002), Juez et al. (1986), Mullakhanbhai \& Larsen (1975), Rodriguez-Valera et al. (1983), Tindall et al. (1989), Tomlinson et al. (1986) and Torreblanca et al. (1986). +, Positive; -, negative; W, weakly positive; ND, not determined.

\begin{tabular}{|c|c|c|c|c|c|c|c|c|}
\hline Characteristic & 1 & 2 & 3 & 4 & 5 & 6 & 7 & 8 \\
\hline Colony colour & Orange-red & Red to orange & Orange-red & Orange-red & Pink & Red & Pink & Salmon pink \\
\hline $\mathrm{NaCl}$ optimum $(\mathrm{M})$ & $2.2-3.4$ & $1.7-2.5$ & $2.0-3.0$ & $2.5-4.3$ & 2.9 & 4.3 & 4.3 & $2.1-2.6$ \\
\hline pH optimum & $6.5-7.0$ & 7.0 & 6.7 & $6.5-7.0$ & 6.5 & 7.2 & 7.5 & $6.4-6.8$ \\
\hline Temperature optimum $\left({ }^{\circ} \mathrm{C}\right)$ & $42-45$ & 45 & 50 & $35-40$ & 35 & 37 & 37 & $32-37$ \\
\hline Nitrate reduction & + & + & + & - & + & + & - & + \\
\hline $\mathrm{H}_{2} \mathrm{~S}$ formation from thiosulfate & + & + & + & + & - & + & + & + \\
\hline \multicolumn{9}{|l|}{ Hydrolysis of: } \\
\hline Starch & + & - & - & - & + & - & - & - \\
\hline Casein & - & - & - & + & + & - & - & - \\
\hline Arabinose & - & + & ND & + & + & + & + & + \\
\hline Galactose & - & + & $\mathrm{ND}$ & + & ND & - & - & + \\
\hline Xylose & - & + & ND & + & + & + & + & + \\
\hline Sucrose & $\mathrm{W}$ & + & $\mathrm{ND}$ & + & + & + & - & + \\
\hline Resistance to rifampicin & - & - & ND & + & - & + & ND & + \\
\hline DNA G $+\mathrm{C}$ content $(\mathrm{mol} \%)$ & $62.2 \pm 0.8$ & $63.4 \pm 0.5$ & 64.2 & 61.8 & 60.0 & $59.5 \pm 0.3$ & 64.5 & 60.5 \\
\hline
\end{tabular}

ampicillin, chloramphenicol, erythromycin, nalidixic acid, neomycin, nystatin, penicillin, tetracycline, streptomycin or kanamycin. The major polar lipids are the $\mathrm{C}_{20} \mathrm{C}_{20}$ derivatives of phosphatidylglycerol, phosphatidylglycerol phosphate methyl ester, diglycosyl glycerol diether and sulfated diglycosyl diether. The DNA G $+\mathrm{C}$ content of DNA of the type strain is $62.2 \pm 0.8 \mathrm{~mol} \%\left(T_{\mathrm{m}}\right)$.

The type strain, ZJ206 ${ }^{\mathrm{T}}$ (=CGMCC $1.5347^{\mathrm{T}}=\mathrm{JCM}$ $13917^{\mathrm{T}}$ ), was isolated from a solar saltern in Zhe-Jiang Province, China.

\section{Acknowledgements}

We thank Xiao-Hong Xu for isolating strain ZJ206 ${ }^{\mathrm{T}}$ and Heng-Lin Cui for performing the lipid extractions. This work was supported by a grant from the Major State Basic Research Development Program of China (973 program) (grant no. 2004CB719604-3) and the China Postdoctoral Science Foundation (grant no. 2005038636).

\section{References}

Asker, D. \& Ohta, Y. (2002). Haloferax alexandrinus sp. nov., an extremely halophilic canthaxanthin-producing archaeon from a solar saltern in Alexandria (Egypt). Int J Syst Evol Microbiol 52, 729-738.
Castillo, A. M., Gutiérrez, M. C., Kamekura, M., Ma, Y.-H., Cowan, D. A., Jones, B. E., Grant, W. D. \& Ventosa, A. (2006). Halovivax asiaticus gen. nov., sp. nov., a novel extremely halophilic archaeon isolated from Inner Mongolia, China. Int J Syst Evol Microbiol 56, 765-770.

De Ley, J., Cattoir, H. \& Reynaerts, A. (1970). The quantitative measurement of DNA hybridization from renaturation rates. Eur $J$ Biochem 12, 133-142.

Elshahed, M. S., Savage, K. N., Oren, A., Gutierrez, M. C., Ventosa, A. \& Krumholz, L. R. (2004). Haloferax sulfurifontis sp. nov., a halophilic archaeon isolated from a sulfide- and sulfur-rich spring. Int J Syst Evol Microbiol 54, 2275-2279.

Grant, W. D., Kamekura, M., McGenity, T. J. \& Ventosa, A. (2001). Class III. Halobacteria class. nov. In Bergey's Manual of Systematic Bacteriology, 2nd edn, vol. 1, pp. 294-301. Edited by D. R. Boone, R. W. Castenholz \& G. M. Garrity. New York: Springer.

Gutierrez, M. C., Kamekura, M., Holmes, M. L., Dyall-Smith, M. L. \& Ventosa, A. (2002). Taxonomic characterization of Haloferax sp. (“H. alicantel") strain Aa 2.2: description of Haloferax lucentensis sp. nov. Extremophiles 6, 479-483.

Huß, V. A. R., Festl, H. \& Schleifer, K. H. (1983). Studies on the spectrophotometric determination of DNA hybridization from renaturation rates. Syst Appl Microbiol 4, 184-192.

Juez, G., Rodriguez-Valera, F., Ventosa, A. \& Kushner, D. J. (1986). Haloarcula hispanica spec. nov. and Haloferax gibbonsii spec. nov., two new species of extremely halophilic archaebacteria. Syst Appl Microbiol 8, 75-79. 
Kamekura, M. \& Kates, M. (1988). Lipids of halophilic archaebacteria. In Halophilic Bacteria II, pp. 25-54. Edited by F. RodriguezValera. Boca Raton, FL: CRC Press.

Kumar, S., Tamura, K. \& Nei, M. (2004). MEGA3: integrated software for molecular evolutionary genetics analysis and sequence alignment. Brief Bioinform 5, 150-163.

Marmur, J. \& Doty, P. (1962). Determination of the base composition of deoxyribonucleic acid from its thermal denaturation temperature. J Mol Biol 5, 109-118.

Mullakhanbhai, M. F. \& Larsen, H. (1975). Halobacterium volcanii spec. nov., a Dead Sea halobacterium with a moderate salt requirement. Arch Microbiol 104, 207-214.

Oren, A., Ventosa, A. \& Grant, W. D. (1997). Proposed minimal standards for description of new taxa in the order Halobacteriales. Int J Syst Bacteriol 47, 233-238.

Rodriguez-Valera, F., Juez, G. \& Kushner, D. J. (1983). Halobacterium mediterranei spec. nov., a new carbohydrate-utilizing extreme halophile. Syst Appl Microbiol 4, 369-381.

Sehgal, S. N. \& Gibbons, N. E. (1960). Effect of some metal ions on the growth of Halobacterium cutirubrum. Can J Microbiol 6, 165-169.

Thompson, J. D., Gibson, T. J., Plewniak, F., Jeanmougin, F. \& Higgins, D. G. (1997). The CLUSTAL_X windows interface: flexible strategies for multiple sequence alignment aided by quality analysis tools. Nucleic Acids Res 25, 4876-4882.

Tindall, B. J., Tomlinson, G. A. \& Hochstein, L. I. (1989). Transfer of Halobacterium denitrificans (Tomlinson, Jahnke, and Hochstein) to the genus Haloferax as Haloferax denitrificans comb. nov. Int J Syst Bacteriol 39, 359-360.

Tomlinson, G. A., Jahnke, L. L. \& Hochstein, L. I. (1986). Halobacterium denitrificans sp. nov., an extremely halophilic denitrifying bacterium. Int J Syst Bacteriol 36, 66-70.

Torreblanca, M., Rodriguez-Valera, F., Juez, G., Ventosa, A., Kamekura, M. \& Kates, M. (1986). Classification of non-alkaliphilic halobacteria based on numerical taxonomy and polar lipid composition, and description of Haloarcula gen. nov. and Haloferax gen. nov. Syst Appl Microbiol 8, 89-99.

Xin, H., Itoh, T., Zhou, P., Suzuki, K., Kamekura, M. \& Nakase, T. (2000). Natrinema versiforme sp. nov., an extremely halophilic archaeon from Aibi salt lake, Xinjiang, China. Int J Syst Evol Microbiol 50, 1297-1303.

Xu, X.-W., Liu, S.-J., Tohty, D., Oren, A., Wu, M. \& Zhou, P.-J. (2005). Haloterrigena saccharevitans sp. nov., an extremely halophilic archaeon from Xin-Jiang, China. Int J Syst Evol Microbiol 55, 2539-2542. 